\title{
POLLUTION STATUS OF TINISHU AKAKI RIVER AND ITS TRIBUTARIES (ETHIOPIA) EVALUATED USING PHYSICO-CHEMICAL PARAMETERS, MAJOR IONS, AND NUTRIENTS
}

\author{
Samuel Melaku ${ }^{\mathrm{a},{ }^{*}}$, Taddese Wondimu ${ }^{\mathrm{b}}$, Richard Dams ${ }^{\mathrm{a}}$ and Luc Moens ${ }^{\mathrm{a}}$ \\ ${ }^{a}$ Laboratory of Analytical Chemistry, Gent University, Institute for Nuclear Sciences, \\ Proeftuinstraat 86, B-9000 Gent, Belgium \\ ${ }^{b}$ Department of Chemistry and Chemical Technology, National University of Lesotho, P.O. \\ Roma 180, Lesotho, Southern Africa
}

(Received December 17, 2004; revised November 8, 2005)

\begin{abstract}
The present investigation provides data on physico-chemical parameters, some major ions and nutrients on water samples of Tinishu Akaki River (TAR), Ethiopia. The $\mathrm{pH}$, temperature, electrical conductivity, total dissolved solids (TDS), dissolved oxygen (DO), chemical oxygen demand (COD), biological oxygen demand (BOD), $\mathrm{Ca}^{2+}, \mathrm{Mg}^{2+}, \mathrm{HCO}_{3}, \mathrm{SO}_{4}{ }^{2}, \mathrm{NO}_{3}{ }^{-}, \mathrm{NO}_{2}{ }^{-}, \mathrm{PO}_{4}{ }^{3}, \mathrm{Cl}$ and $\mathrm{NH}_{3}$ have been determined to asses the chemical status and pollution levels of the TAR and its tributaries. The values of certain parameters have been evaluated with respect to the acceptable standard limits for drinking and surface water to indicate the pollution level of the TAR. Increasing in BOD, nitrite, ammonia and phosphate and decreasing in DO concentrations downstream of the TAR were observed with increasing domestic, industrial and agricultural activities. The mean $\mathrm{Ca}^{2+}$, $\mathrm{Mg}^{2+}, \mathrm{Cl}, \mathrm{SO}_{4}{ }^{2-}, \mathrm{HCO}_{3}{ }^{-}, \mathrm{NO}_{3}{ }^{-}$and $\mathrm{PO}_{4}^{3-}$ concentrations exceeded their most common natural concentrations' (MCNC) in world rivers by a factor of 6.3, 7.6, 27.2, 6.8, 9.2, 19 and 390, respectively.
\end{abstract}

KEY WORDS: Tinishu Akaki River, Water pollution, Ethiopia

\section{INTRODUCTION}

A major concern of the presence of polluting elements in the aquatic environment is related to the negative health effects they may cause in humans, animals, and plants [1]. Pollution of water bodies from technological activities such as industrial effluents and agricultural chemicals is considered a minor threat in developing countries like Ethiopia, though urban water pollution is growing at alarmingly faster rates. The physical and chemical characteristics of rivers under natural conditions are influenced by a number of factors including topography, geology, and inputs through rainwater, water/rock interaction [2] and climate. River systems are also influenced by anthropogenic factors; disturbance due to pollution and other human interferences gives rise to specific problems [3, 4]. Moreover, agricultural runoff is an important source of pollutants in the catchments [5]. Study of the major ions and nutrients composition of river water (e.g., $\mathrm{Ca}^{2+}, \mathrm{Mg}^{2+}, \mathrm{HCO}_{3}^{-}, \mathrm{SO}_{4}^{2-}, \mathrm{NO}_{3}^{-}, \mathrm{NO}_{2}^{-}, \mathrm{PO}_{4}^{3-}, \mathrm{Cl}^{-}$and $\mathrm{NH}_{3}$ ) reveals the nature of weathering and a variety of other natural and anthropogenic processes [6] such as the input of pollutants into the river system from non-point sources (e.g. urban runoff) and point sources (e.g. unlicensed discharges of effluents from different industries). Knowledge of the state of the water quality of rivers and the changes produced by human activities is not only the first step towards prevention and creation of awareness among the public but also solving water pollution problems [3].

The TAR represents typical urban water systems in developing countries. It extends over very densely populated areas in Addis Ababa, Ethiopia, receives discharges from industrial and domestic sources and is subject to intensive exploitation by domestic, industrial and agricultural

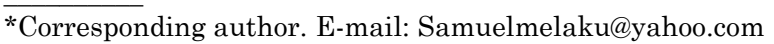


activities. Such activities often result in the introduction of nutrients and potentially hazardous levels of trace metals and domestic wastes into the riverine ecosystem.

Limited reports dealing with the quality of TAR have appeared in the literature [7]. Extensive physico-chemical analyses along with major ions and nutrients were performed on the TAR water samples to determine typical indicators of pollution such as ammonia, nitrite, COD, phosphate, sulfate, etc. Itanna [8] evaluated the elemental composition of vegetables irrigated with the TAR in an implicit attempt to determine its pollution status. Despite its foul odour, black colour and toxicity; the TAR is still used for various purposes including irrigation, swimming and cattle watering. These observations may reveal absence of policies protecting water systems and/or overt monitoring studies on TAR with the view to assessing temporal variations and thereby public awareness.

The primary aim of this study was to identify the relative importance of anthropogenic influences on the water chemistry of the TAR, Ethiopia. To this end, the spatial variability of major ions and nutrients was examined. A secondary aim was to assess the water quality parameters of TAR and its tributaries in an attempt to fill the scientific information gap with respect to the pollution of TAR. The results obtained from the two campaigns allow an overall evaluation of water quality for the investigated contaminants.

\section{EXPERIMENTAL}

\section{Water sampling}

Water samples for physico-chemical parameters were collected in 1 liter polyethylene bottles (VWR international, Belgium) and investigated at each site on two separate sampling occasions (between November and January 2002-2003, campaign I, and 2003-2004, campaign II) at 23 representative sites (Figure 1). The various sampling sites were selected based on access, safety, potential sources of pollutions and waste disposal activities. These sites were evenly distributed along the course of the Tinishu Akaki River giving more emphasis to the most polluted sites. Water samples for major ions, nutrients and ammonia $\left(\mathrm{Ca}^{2+}, \mathrm{Mg}^{2+}, \mathrm{HCO}_{3}{ }^{-}, \mathrm{SO}_{4}{ }^{2-}, \mathrm{PO}_{4}{ }^{3-}, \mathrm{NO}_{2}{ }^{-}\right.$, $\mathrm{NO}_{3}{ }^{-} \mathrm{Cl}^{-}$and $\mathrm{NH}_{3}$ ) were taken only once, during the second campaign.

Water samples from sites with minimal anthropogenic disturbance, upstream, were also collected, so that changes induced by further urbanization, industrially and agriculturally active areas of the catchment's can be detected, and an assessment can be made of potential environmental detriment. Water samples for COD, BOD, major ion and nutrients were taken in 1-liter polyethylene bottles, transferred to the lab shortly after sampling and stored at $4{ }^{\circ} \mathrm{C}$ in the dark until analysis.

\section{Analytical procedures}

\section{Physico-chemical parameters}

Temperature, $\mathrm{pH}$, dissolved oxygen, conductivity and total dissolved solid measurements were made in the field using a Mettler Toledo portable meter, calibrated at the beginning of the sample run using standard-buffers at field temperature and checked at each site. Measurements were made at each sampling site at the same time as the water samples were collected. For DO measurements, zero point calibration was achieved by immersion of the oxygen electrode in a 4 $\% \mathrm{Na}_{2} \mathrm{SO}_{3}$ solution to ensure full-scale calibration. It was also calibrated in the field using DO standard solution. 


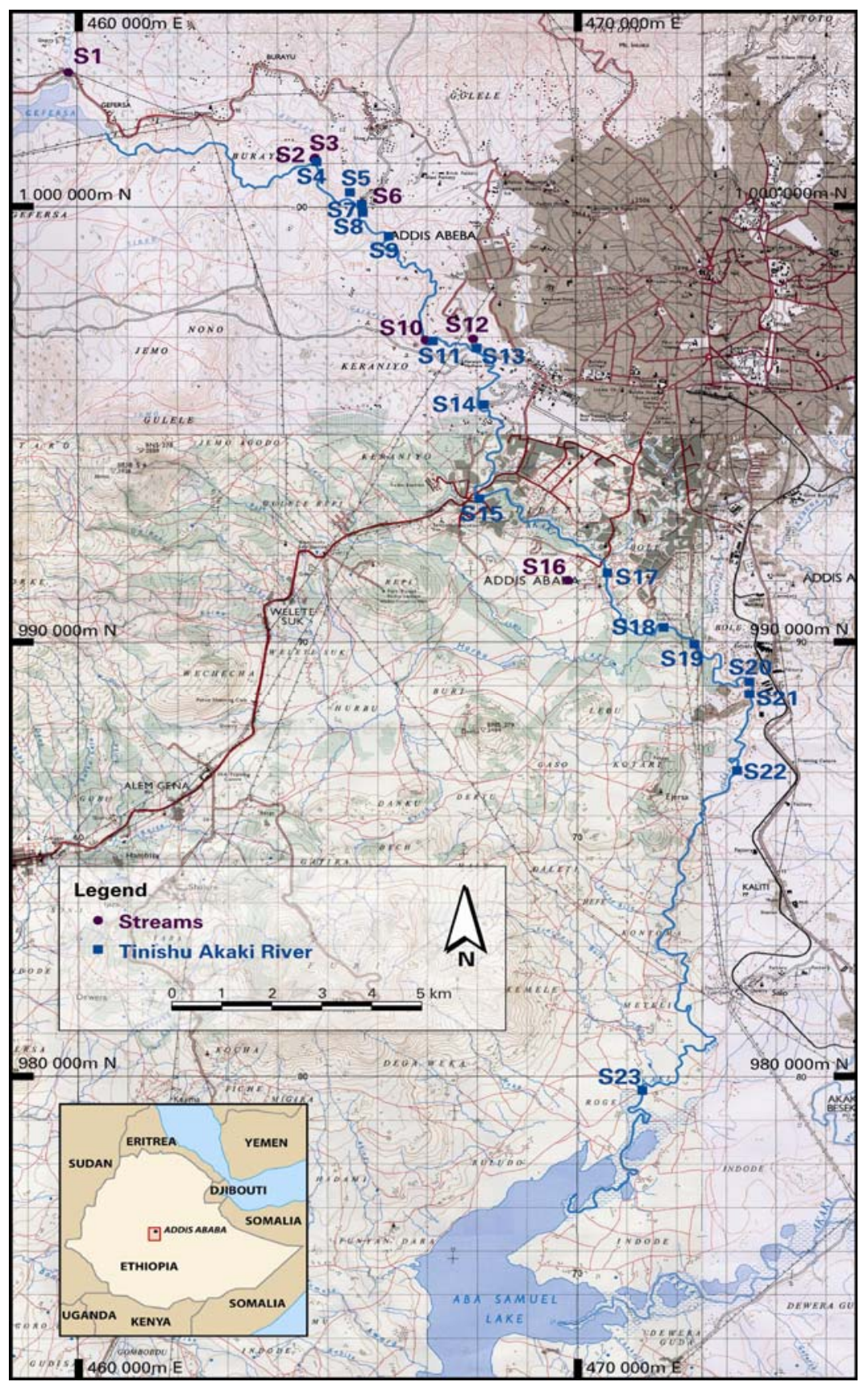

Figure 1. Location of sampling sites in Tinishu Akaki River and its tributaries, Ethiopia. 
Chemical and biological oxygen demand (COD and BOD)

COD and BOD were determined according to standard procedure (Standard Methods $5210 \mathrm{~B}$ ) [9]. HACH - Model M-45600 COD Reactor, Germany, which can digest up to 25 samples simultaneously, was used to digest water samples for COD measurement. The DR/2010 (HACH, Germany) a microprocessor-controlled, single-beam, data logging spectrophotometer designed for colorimetric testing was used for measuring the COD. BOD incubator (Stuart, UK), thermostatically controlled at $20 \pm 1{ }^{\circ} \mathrm{C}$, and BOD bottles (VWR international, Belgium) were used to incubate water samples for five days.

\section{Major ions and nutrients}

The analyses of major ions and nutrients were performed as described elsewhere [9]. Briefly, the ammonia and nitrite concentrations were determined spectrophotometrically with the Nessler's method (Standard Methods 4500- $\mathrm{NH}_{3} \mathrm{C}$ ) and diazotization method (Standard Methods 4500$\mathrm{NO}_{2}^{-}$A), respectively. Colorimetric method was used for the determination of nitrate by reducing it to nitrite in the presence of cadmium treated with copper sulfate (Standard Methods $4500-\mathrm{NO}_{3}{ }^{-} \mathrm{E}$ ) and phosphate (Standard Methods 4500-P C, 1992). Sulfate was determined by turbidimetric method (Standard Methods $4500-\mathrm{SO}_{4}{ }^{2-}$ ). Titrimetry was used for bicarbonate alkalinity (Standard Method (2320 B), chloride concentration using mercury nitrate (Standard Methods $4500-\mathrm{Cl}^{-} \mathrm{C}$ ), and calcium and magnesium concentrations by EDTA (Standard Methods 2340). HACH DR/4000 U spectrophotometer (Germany) was used for anions and ammonia analysis.

\section{RESULTS AND DISCUSSION}

\section{Physico-chemical parameters}

The results of the physico-chemical parameters and the major ions and nutrients of the TAR water samples made in situ and in the laboratory are summarized in Tables 1 and 2, respectively.

The temperature of the water samples analyzed ranged from 12.4 to $22.1{ }^{\circ} \mathrm{C}$ and was found to be nearly always above the maximum permissible limit (Table 3 ) of Canadian Council of Ministers for Environment (CCME) guidelines for community water used as aesthetic object [10] and was relatively constant during this study.

TAR has hydrogen ion concentrations near neutral to slightly alkaline $\mathrm{pH}$ 7.3-8.9 which is the usual range in river water. The slight alkalinity could be possibly from calcium carbonate bedrock weathering or may reflect the importance of dissolution of limestone and dolomites in the watershed. All values are within the limit of the CCME guidelines for livestock watering and irrigation water [10], i.e., 5-9.5 and 5-9, respectively, and WHO (Table 3).

The EC is a valuable indicator of the amount of material dissolved in water and its value in the TAR water samples ranged from $56-1268 \mu \mathrm{S} / \mathrm{cm}$. The recommended value [11] of EC for potable waters is below $2500 \mu \mathrm{S} / \mathrm{cm}$. The lowest and the highest EC values in TAR water were observed at S1 and S22, respectively. Moreover, the level of EC reflected worsening of river quality from up to down stream of the TAR, but within permissible limits of the WHO (Table 3). Generally, the physico-chemical parameters investigated increased from up river to down river owing to a natural enrichment in electrolytes, possibly due to phenomena of mineralization or weathering of sediments, and probably largely due to discharge of industrial and domestic wastes. The water quality of the sites S6 to S23 was strongly degraded resulting in low dissolved oxygen and high conductivity. 
Table 1. Physico-chemical parameters of Tinishu Akaki River.

\begin{tabular}{|c|c|c|c|c|c|c|c|c|c|c|c|c|c|c|}
\hline Site & \multicolumn{2}{|c|}{$\begin{array}{c}\mathrm{T} \\
\left({ }^{\circ} \mathrm{C}\right) \\
\end{array}$} & \multicolumn{2}{|c|}{$\mathrm{pH}$} & \multicolumn{2}{|c|}{$\begin{array}{c}\text { Conductivity } \\
\mu \mathrm{S} / \mathrm{cm}\end{array}$} & \multicolumn{2}{|c|}{$\begin{array}{c}\mathrm{TDS} \\
\mathrm{mg} / \mathrm{L}\end{array}$} & \multicolumn{2}{|c|}{$\begin{array}{c}\mathrm{DO} \\
\mathrm{mg} / \mathrm{L}\end{array}$} & \multicolumn{2}{|c|}{$\begin{array}{l}\mathrm{COD} \\
\mathrm{mg} / \mathrm{L}\end{array}$} & \multicolumn{2}{|c|}{$\begin{array}{l}\mathrm{BOD}_{5} \\
\mathrm{mg} / \mathrm{L}\end{array}$} \\
\hline Campaign & I & II & I & II & I & II & I & II & I & II & I & II & I & II \\
\hline S1 & - & 21.2 & - & 8.1 & & 56 & & 28 & & 6.7 & & 18 & - & 7.6 \\
\hline $\mathrm{S} 2$ & 15 & 18.9 & 7.1 & 8.6 & 209 & 202 & 106 & 104 & 3.4 & 5.2 & $\overline{12}$ & 17 & - & 7.6 \\
\hline S3 & 15 & 18.5 & 8.1 & 8.6 & 156 & 142 & 79 & 71 & 3.2 & 4.8 & 12 & 28 & & 11 \\
\hline S4 & 15.8 & 18.5 & 8.1 & 8.6 & 163 & 147 & 81 & 73 & 2.3 & 4.8 & 13 & 4 & 2.7 & _ \\
\hline S5 & 15.7 & 14 & 8.4 & 7.9 & 161 & 170 & 80 & 85 & 2.2 & 5.1 & 23 & 8 & 5.8 & - \\
\hline S6 & 18.7 & 15.2 & 8.2 & 7.8 & 273 & 390 & 146 & 200 & 2.5 & 1.2 & 76 & 27 & 15 & 11 \\
\hline S7 & 19.7 & 16.6 & 8.9 & 7.8 & 714 & 785 & 358 & 396 & 1.1 & 1.3 & 360 & 426 & 138 & 137 \\
\hline S8 & 18.8 & 16.5 & 8.9 & 7.9 & 729 & 970 & 366 & 492 & 0.9 & 0.8 & 280 & 280 & 86 & 85 \\
\hline S9 & 19.7 & 18.8 & 8.1 & 7.6 & 952 & 1225 & 478 & 626 & 1.1 & 1.5 & 266 & 130 & 80 & 42 \\
\hline $\mathrm{S} 10$ & 17.9 & 12.4 & 7.6 & 8.1 & 940 & 318 & 473 & 161 & 1.2 & 5.2 & 46 & 13 & - & 5 \\
\hline S11 & 18.7 & 14.1 & 7.7 & 7.9 & 1053 & 1143 & 525 & 569 & 1.8 & 2.4 & 29 & 60 & 8.8 & 18 \\
\hline S12 & 17.4 & 13.7 & 7.9 & 8 & 883 & 882 & 440 & 443 & 0.6 & 1.1 & 70 & 69 & 17 & 22 \\
\hline S13 & 17.8 & 14.2 & 7.8 & 8.2 & 1116 & 1055 & 557 & 533 & 1.3 & 1.6 & 44 & 66 & 16 & 22 \\
\hline S14 & 19 & 14.1 & 7.9 & 7.9 & 971 & 994 & 487 & 497 & 2.1 & 3.1 & 49 & 37 & 7.2 & 13 \\
\hline S15 & 15.3 & 14.5 & 7.8 & 7.4 & 885 & 883 & 442 & 443 & 1.9 & 2.3 & 30 & 52 & 9 & 16 \\
\hline S16 & - & 13.8 & $1-$ & 8.3 & - & 938 & & 479 & - & 2.7 & - & 314 & - & 97 \\
\hline S17 & 17 & 14.4 & 7.9 & 7.9 & 908 & 876 & 456 & 454 & 0.7 & 1.4 & 275 & 352 & $\overline{6} 1$ & 113 \\
\hline S18 & 18.8 & 16.9 & 7.4 & 7.6 & 912 & 873 & 460 & 439 & 0.1 & 1.1 & 263 & 85 & 91 & 33 \\
\hline S19 & 19 & 17.4 & 7.6 & 7.8 & 874 & 849 & 439 & 426 & 0.2 & 1.2 & 216 & 90 & 62 & 33 \\
\hline S20 & 18.8 & 16.7 & 7.7 & 7.9 & 914 & 915 & 459 & 459 & 1.4 & 2.9 & 94 & 237 & 40 & 77 \\
\hline S21 & 19.4 & 16.9 & 7.6 & 8 & 979 & 931 & 491 & 467 & 1.3 & 4.2 & 533 & 239 & 204 & 77 \\
\hline S22 & 21.8 & 21.7 & 7.6 & 7.8 & 1150 & 1269 & 577 & 639 & 0.6 & 0.01 & 239 & 158 & 89 & 44 \\
\hline S23 & 20.9 & 22.1 & 7.8 & 8 & 972 & 1116 & 488 & 559 & 0.4 & 0.01 & 121 & 128 & 31 & 43 \\
\hline
\end{tabular}

Table 2. Concentrations (mg/L) of major ions and nutrients in Tinishu Akaki River.

\begin{tabular}{|l|l|l|l|l|l|l|l|l|l|}
\hline Site & $\mathrm{Ca}^{2}$ & $\mathrm{Mg}^{2+}$ & $\mathrm{Cl}^{-}$ & $\mathrm{SO}_{4}{ }^{--}$ & $\mathrm{HCO}_{3}^{-}$ & $\mathrm{NO}_{3}^{-}$ & $\mathrm{NO}_{2}^{-}$ & $\mathrm{NH}_{3}$ & $\mathrm{PO}_{4}{ }^{3-}$ \\
\hline S4 & 22 & 3.4 & 4.5 & 10.2 & 87 & 2.64 & - & - & 0.06 \\
S5 & 19 & 7.3 & 19.5 & 4.9 & 87.8 & 1.85 & - & 0.6 & 0.05 \\
S6 & 45 & 16 & 22 & & 198 & 4.29 & 0.12 & 0.4 & 0.04 \\
S7 & 38 & 8.3 & 88 & 65.4 & 199 & - & - & 20.8 & 0.85 \\
S8 & 32 & 11.7 & 108 & 65.7 & 185 & - & - & 20.6 & 0.67 \\
S9 & 40 & 14.6 & 129 & 37.2 & 212 & - & - & 17.9 & 0.18 \\
S10 & 37 & 11.2 & 21.5 & - & 154 & 5.83 & 0.42 & 0.8 & 0.1 \\
S11 & 48 & 15.6 & 189 & 70.8 & 198 & 9.24 & 1.06 & 7.1 & 0.14 \\
S12 & 63 & 20.9 & 85 & - & 381 & - & 0.15 & 17.4 & 4.95 \\
S13 & 54 & 16 & 193 & 56.7 & 234 & 5.86 & 1.03 & 9.3 & 1.52 \\
S14 & 50 & 17 & 154 & 63.1 & 251 & 1.72 & 0.3 & 9.3 & 1.8 \\
S15 & 58 & 16.5 & 156 & 60.6 & 234 & 5.72 & 1.22 & 7.3 & 1.72 \\
S16 & 58 & 28.2 & 159 & 15.1 & 429 & - & - & 30 & 14.8 \\
S17 & 64 & 23.8 & 138 & 39.1 & 332 & - & - & 25.1 & 5.21 \\
S18 & 64 & 31.6 & 125 & 33.4 & 386 & - & - & 30.4 & 6.05 \\
S19 & 64 & 36 & 112 & 28.8 & 395 & - & - & 24 & 8.62 \\
S20 & 65 & 26.3 & 115 & 27.8 & 412 & - & - & 28.2 & 7.32 \\
S21 & 64 & 23.3 & 121 & 25.2 & 417 & - & - & 19.5 & 6.45 \\
S22 & 67 & 19 & 91 & 22.9 & 437 & - & - & 34.9 & 9.63 \\
S23 & 61 & 17.5 & 87.5 & 23.3 & 407 & - & - & 25.5 & 8.77 \\
World rivers & 8.0 & 2.4 & 3.9 & 4.8 & 30.5 & 0.1 & - & & 0.01 \\
\hline
\end{tabular}

*MCNC: Most Common Natural Concentrations (median values) for minimally polluted major world rivers and their tributaries [6]. 
Table 3. Recommended water quality criteria.

\begin{tabular}{|c|c|c|c|}
\hline Parameter & Desirable limit & Maximum permissible limit & Organization/Body \\
\hline Temperature, ${ }^{\circ} \mathrm{C}$ & & 15 & CCME \\
\hline $\mathrm{pH}$ & $7.0-8.5$ & $6.5-9.2$ & WHO \\
\hline $\mathrm{DO}, \mathrm{mg} / \mathrm{L}$ & $5.5-9.5$ & & CCME \\
\hline Conductivity, $\mu \mathrm{S} / \mathrm{cm}$ & 750 & 2500 & WHO \\
\hline $\mathrm{TDS}, \mathrm{mg} / \mathrm{L}$ & 500 & 1500 & ICMR \\
\hline Nitrate, $\mathrm{mg} / \mathrm{L}$ & 25 & 50, drinking water & $\mathrm{EC}$ \\
\hline & - & 45 & WHO \\
\hline Chloride, $\mathrm{mg} / \mathrm{L}$ & $100-700$ & Irrigation water & CCME \\
\hline Phosphate, mg/L & 0.35 & 6.1 & $\mathrm{EC}$ \\
\hline & 1 & - & WHO \\
\hline Calcium, mg/L & 1000 , for livestock & & CCME \\
\hline Total hardness, $\mathrm{mg} / \mathrm{L} \mathrm{CaCO}_{3}$ & 100 & 500 & EPA, ICMR \\
\hline Sulfate, $\mathrm{mg} / \mathrm{L}$ & $<1000$, for livestock & & CCME \\
\hline Nitrite, mg/L & 0.06 & & CCME \\
\hline & & 0.1 & $\mathrm{EC}$ \\
\hline $\mathrm{NH}_{3}, \mathrm{mg} / \mathrm{L}$ & $\begin{array}{l}1.37-2.20 \text {, for aquatic } \\
\text { life }\end{array}$ & & CCME \\
\hline
\end{tabular}

CCME: Canadian Council of Minister for Environment; WHO: World Health Organization; ICMR: Indian Council of Medical Research; EC: European Community; EPA: Environmental Protection Agency.

Table 4. The UK General Quality Assessment (GQA) for rivers and hardness description used in the UK.

\begin{tabular}{|l|l|l|l|c|l|}
\hline GQA grade & Description & $\mathrm{BOD}(\mathrm{mg} / \mathrm{L})$ & $\mathrm{NH}_{3}(\mathrm{mg} / \mathrm{L} \mathrm{N})$ & Hardness $\left(\mathrm{mg} / \mathrm{L} \mathrm{CaCO}_{3}\right)$ & Description \\
\hline A & Very good & 2.5 & 0.25 & $0-50$ & Soft \\
B & Good & 4.0 & 0.6 & $50-100$ & Moderately soft \\
C & Fairly good & 6 & 1.3 & $100-150$ & Slightly hard \\
D & Fair & 8 & 2.5 & $150-200$ & Moderately hard \\
E & Poor & 15 & 9 & $200-300$ & Hard \\
F & Bad & $>15$ & $<9$ & $>300$ & Very hard \\
\hline
\end{tabular}

The TDS in the TAR and its tributaries vary from 28 to $639 \mathrm{mg} / \mathrm{L}$ with more than $84 \%$ of the samples having TDS greater than $100 \mathrm{mg} / \mathrm{L}$. TDS shows negligible temporal and considerable spatial variations. Again a marked increase from upstream to downstream is seen. The TDS values during both campaigns are more or less comparable. The maximum values were obtained at S22 during both campaigns. Water samples from sites S7 to S23 during both campaigns, except S10 during the second campaign, showed values larger than $283 \mathrm{mg} / \mathrm{L}$, which is the mean of the world large rivers [2]. In the present investigation, the TDS values in the TAR water samples at sites S11, S13, S22 during both campaigns and S9 during campaign II were found to be above the CCME guidelines for drinking water, i.e., $500 \mathrm{mg} / \mathrm{L}$ and the rest were below this maximum limit. The variations in TDS in TAR can probably be related to pollution through the discharge of domestic and industrial wastes into the TAR.

The DO concentration of the TAR ranged from 0.01 (S22, S23) to $6.7 \mathrm{mg} / \mathrm{L}(\mathrm{S} 1)$. In general the DO concentration declined critically from up to downstream of the river, again an indication of worsening water quality. The levels of DO in all sites except S1 were found critically low and do not fulfil the CCME guideline for the protection of aquatic life [10] i.e., 5.5-9.5 mg/L (Table 3). The lower DO level, $<3 \mathrm{mg} / \mathrm{L}$, causes anaerobic conditions and bad odors of the TAR.

\section{Chemical and biological oxygen demand (COD and BOD)}

The COD for the TAR water ranged from 4.0 (S4) to $533 \mathrm{mg} / \mathrm{L}$ (S21). The BOD varies from 2.7 (S4) to $204.5 \mathrm{mg} / \mathrm{L}$ (S21). Half of the sampling sites contained more than $15 \mathrm{mg} / \mathrm{L}$ of BOD values (Table 1), exceeding the UK general water quality assessment criteria (Table 4) categorized under Grade F, i.e., bad [12]. The relatively high BOD values at sites S7 to S9 and 
S17 to S23 during both campaigns indicates problems of industrial, municipal and domestic sewage pollutions at different locations along the river. The water does not fulfil the UK water quality demand at sites S7 to S9, S11 to S13, S15 to S23 (during campaign I) and S6 to S9, S12, $\mathrm{S} 13$, and S17 to S23 (during campaign II).

The higher BOD values along with the lower DO (Figure 2) accompanied by the continuous input of all kinds of wastes into the TAR overestimated the assimilative (the natural selfpurification) capacity of the TAR. This in turn greatly impairs the water quality of the river and harms aquatic life.

\section{A. Trends of BOD and DO, campaign I}

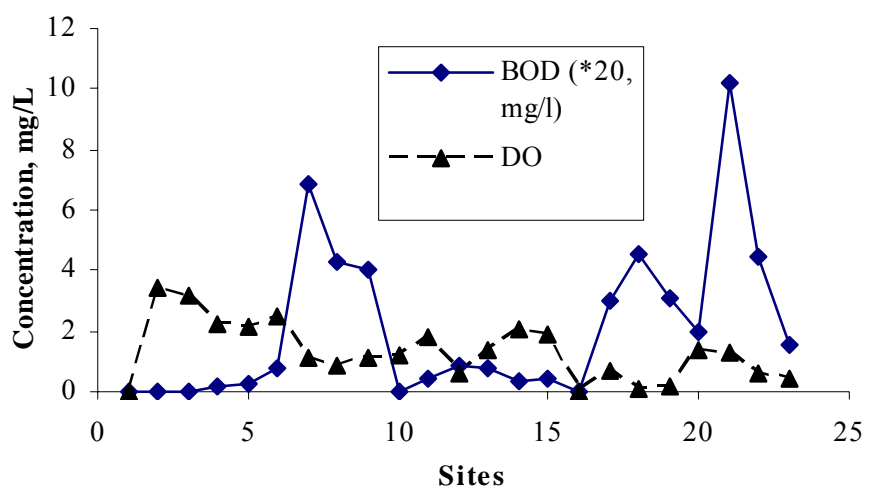

\section{B. Trends of BOD and DO, Campaign II}

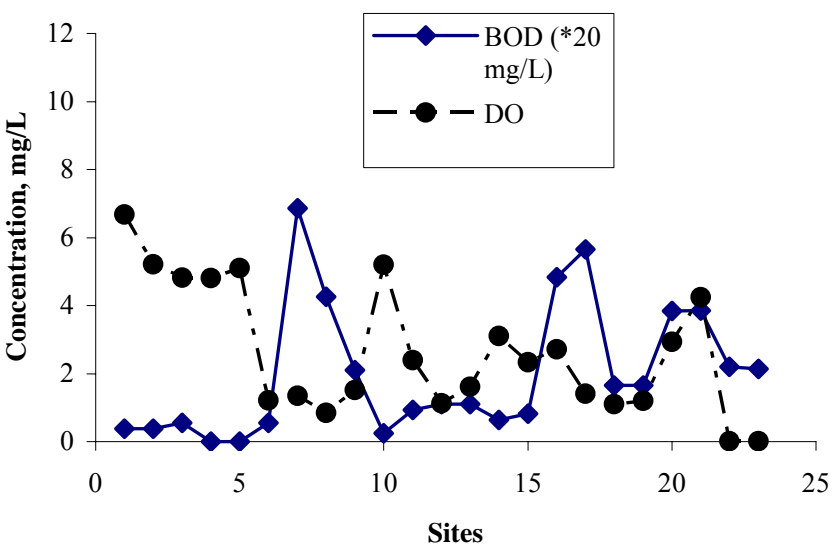

Figure 2. Trends of $\mathrm{BOD}_{5}$ and DO: (A) Campaign I and (B) Campaign II.

\section{Major ions and nutrients}

\section{Calcium, magnesium, hardness and bicarbonate}

The limits of $\mathrm{Ca}$ and $\mathrm{Mg}$ ions in potable water range from 75 to $200 \mathrm{mg} / \mathrm{L}$ and 50 to $100 \mathrm{mg} / \mathrm{L}$, respectively [13]. Increasing water hardness generally decreases metal toxicity, possibly due to $\mathrm{Ca}$ competition on the cell surface [14]. In the present study, the $\mathrm{Ca}$ and $\mathrm{Mg}$ ion content of the 
TAR water samples ranged from 19 (S5) to $67 \mathrm{mg} / \mathrm{L}$ (S22) and 3.4 (S1) to 36 (S19), respectively. The $\mathrm{Ca}$ ion concentration was found below the limit given by the CCME for livestock use (Table 3). The total hardness of water samples in the TAR was also found within the maximum permissible limit of EPA, i.e., $500 \mathrm{mg} / \mathrm{L}$ (Table 3). The total hardness, as $\mathrm{CaCO}_{3}$, varied from 48 (S5) to 168 (S22). Water samples from the different sites were found to be soft; moderately soft; slightly hard and moderately hard (Table 4), according to hardness description used in the UK [12].

The bicarbonate concentration in the TAR varied from 87 (S4) to $437 \mathrm{mg} / \mathrm{L}$ (S22). Alkalinity is directly related to the bicarbonate in solution when the hydrogen ion concentration is low. The alkalinity generated within the TAR possibly comes from calcium carbonate bedrock weathering.

The base cations ( $\mathrm{Ca}$ and $\mathrm{Mg}$ ) as well as alkalinity are associated with weathering of the bedrock and ground water discharges [15] and with the extent of weathering linked to the reactivity of the rock, the surface area of contact between the rock and the river water. Moreover, the good correlations between $\mathrm{Ca}^{2+}$ and $\mathrm{HCO}_{3}^{-}\left(\mathrm{r}^{2}=0.84\right)$ and $\mathrm{Ca}^{2+}+\mathrm{Mg}^{2+}$ and $\mathrm{HCO}_{3}^{-}\left(\mathrm{r}^{2}=0.76\right)$ suggest that calcite and dolomite weathering also contribute $\mathrm{Ca}$ ions to the river water.

Calcium and bicarbonate dominate the major ions present within the TAR. Also their concentrations increase from up to down stream (Table 2). The alkalinity varies even though the $\mathrm{pH}$ remains relatively constant and this reflects large changes in $\mathrm{CO}_{2}[16] . \mathrm{Ca}^{2+}$ and alkalinity show differentiation between the relatively clean upstream and the polluted urban and industrial southern part of the river [15].

Nitrate, nitrite, ammonia and phosphate

The concentration of nitrate and nitrite in river water, as measured, were found to be 1.7 (S14) to $9.2 \mathrm{mg} / \mathrm{L}(\mathrm{S} 11)$ and 0.1 (S6) to $1.2 \mathrm{mg} / \mathrm{L}$ (S15), respectively. According to WHO [11], the maximum concentration of nitrate ion for public water supplies is $45 \mathrm{mg} / \mathrm{L}$. The guidelines (GL) for drinking water quality of European Community [17] provide reference value of $25 \mathrm{mg} / \mathrm{L}$ and maximum admissible limit of $50 \mathrm{mg} / \mathrm{L}$ for nitrate. The concentration of nitrate in TAR water samples was within these maximum permissible limits. On the other hand the concentration of nitrite at S6 and S10 to S15 was above the recommended values given by CCME and EC (Table 3). Water samples from S7 to S9, S16 to S23 (for nitrate and nitrite) and S4, S5 (for nitrite) were below detection limits, i.e., 0.5 and $0.01 \mathrm{mg} / \mathrm{L}$, respectively.

The ammonia content varied from 0.4 (S6) to $35 \mathrm{mg} / \mathrm{L}$ (S22). In the river water samples for this survey of the study area S5, S6 and S10 were found to be fair to very good according to the UK water quality criteria [12] and for S7-S9 and S11-S23 where the ammonia levels exceeded. The high level of ammonia might be due to the leaching of fertilizer residues used on agricultural farms into the river system. Important increases in ammonia concentrations, occasionally accompanied by lower $\mathrm{NO}_{3}{ }^{-}$values, suggest suboxic conditions [14] especially at sites $\mathrm{S} 7$ to S9 and S16 to S23. Ammonia provides the main form of nitrogen, i.e., an average of $88.6 \%$ of the nitrogen species (average concentrations, $16.4,1.9$ and $0.21 \mathrm{mg} / \mathrm{L}$ for ammonia, nitrate and nitrite, respectively). However, these nutrient variables showed marked differences depending on the sampling locations.

The phosphate concentration in the TAR varied from 0.04 (S6) to $15 \mathrm{mg} / \mathrm{L}$ (S16). Again an increase in phosphate value is seen from up to downstream. Although much lower in concentration at S4-S15 and S17, phosphorus levels at S16 and S18-S23 were above the maximum permissible limit value given by the European community, i.e. $6.1 \mathrm{mg} / \mathrm{L}$ (Table 3). This could be possibly as a consequence of urban and/or agricultural activities. Nevertheless, the mean concentrations of $\mathrm{NH}_{3}$ and $\mathrm{PO}_{4}{ }^{3-}$ showed distinct peaks at site $\mathrm{S} 16$ to $\mathrm{S} 23$. The more pronounced phosphate peak at S16 could be possibly derived from urban waste discharges, 
sewage effluents, agricultural run-off (i.e., mainly from fertilizers), and slaughterhouse wastes of Kera.

Phosphate and nitrate typically have short residence times in the water column after entering the river, primarily due to uptake by phytoplankton, but in the case of phosphate, adsorption to particulate matter and subsequent sedimentation is also an important net loss factor [6]. Such behavior explains the discrete concentration peaks for nitrate and phosphate (Table 2), with minimal carry-over to the immediate downstream sampling sites.

The high concentration levels of phosphate and nitrate ions from the high pollution river water source could be attributed to the leaching of fertilizer residues from agricultural farms and the use of phosphate additives in detergent formulations, which can be eroded into the river system during the disposal of wastewaters generated municipally, domestically or industrially. Moreover, significant correlation between calcium and phosphate $\left(r^{2}=0.8\right)$ were observed, thus suggesting a common source for the polluting substances.

\section{Chloride and sulfate}

Chloride ion content (Table 2) in TAR water samples ranged from 4.5 (S4) to $193 \mathrm{mg} / \mathrm{L}$ (S13), which is within the limits of the CCME for using as irrigation water (Table 3) and the limits for domestic purpose fixed by EPA [18], i.e., $250 \mathrm{mg} / \mathrm{L}$. The possible sources of chloride at S13 could be municipal and domestic sewages.

The sulfate ion in the river waters may have several sources, that is, dissolution of evaporites such as gypsum, oxidation of sulfides, and atmospheric input. The sulfate ion concentration in TAR ranged from 4.9 (S5) to $65.7 \mathrm{mg} / \mathrm{L}(\mathrm{S} 8)$ and all water samples were within the limit given by CCME for livestock use, i.e. $1000 \mathrm{mg} / \mathrm{L}$ (Table 4).

In general, the decreasing concentration of sulfate from site 14 to 23 was accompanied by an increase in bicarbonate alkalinity. In this study, no significant trend is observed for bicarbonate alkalinity and $\mathrm{pH}$. This is partially different from European rivers where an increase in sulfate concentration is mostly accompanied by a decrease in alkalinity and $\mathrm{pH}$ [19].

The relative significance $(\mathrm{mg} / \mathrm{L})$ of the major cations and anions is: $\mathrm{Ca}^{2+}>\mathrm{Mg}^{2+}$ and $\mathrm{HCO}_{3}{ }^{-}$ $>\mathrm{Cl}^{-}>\mathrm{SO}_{4}{ }^{2-}$ which is in accordance with the results established for the world rivers [20] for cations but differ for the anions, i.e. $\mathrm{HCO}_{3}{ }^{-}>\mathrm{SO}_{4}{ }^{2-}>\mathrm{Cl}^{-}$. Bicarbonate is the dominant anion for the majority of the samples $\left(87\right.$ to $437 \mathrm{mg} / \mathrm{L}$ ). The second major anion is $\mathrm{Cl}^{-}$and its concentration averages $106 \mathrm{mg} / \mathrm{L}$ followed by $\mathrm{SO}_{4}{ }^{2-}, 32.5 \mathrm{mg} / \mathrm{L}$. So, $\mathrm{SO}_{4}{ }^{2-}, \mathrm{HCO}_{3}{ }^{-}$, and $\mathrm{Cl}^{-}$, together account for $98.6 \%$ of the total anions in most of these water samples.

Elevated concentrations of these ions are characteristic of both domestic and trade effluent, although the composition of effluent varies considerably according to the extent and nature of industrial activity in the sewerage area and the treatment before release into the receiving water.

\section{CONCLUSIONS}

It has been evident from our findings that, the water quality of the TAR shows pattern of behavior linked to anthropogenic sources with the intensity of human pressure associated with industrial effluent, domestic wastes and agricultural activities. Most of the measured variables showed a similar declining quality trend from up to downstream of the river (Tables 1 and 2). The major tributaries of the TAR such as the Leku stream (S6), Werenchiti stream (S12) and Kera stream (S16) also added to the pollution load of the TAR, as they are used as a receptacle of all kinds of wastes. Although this study identifies the relative importance of anthropogenic inputs of polluting components, further work is required to quantify, where necessary, the contributions to the pollution load from the various key sources at each site. 


\section{ACKNOWLEDGEMENTS}

Financial support by the Belgian Technical Co-operation; free access to their laboratory by Mr. Teferi Zeleke (AAWSA), Dr. Wondimagegn Mammo, Dr. Yonas Chebude and Dr. Feleke Zewge (Department of Chemistry, Addis Ababa University), Dr. Fassil Assefa (Department of Biology, AAU); free transportation facility by the Department of Geology (AAU); and continuous encouragement by Dr. Gizachew Alemayehu and Dr Tarekegn Gebreyesus (Department of Chemistry, AAU) are gratefully acknowledged.

\section{REFERENCES}

1. Munk, L-A.; Faure, G. Appl. Geochem. 2004, 19, 1065.

2. Han, G.; Liu, C-O. Chem. Geology 2004, 204, 1.

3. Perona, E.; Bonilla, I.; Mateo, P. The Sci. Total Environ. 1999, 241, 75.

4. Davide, V.; Pardos, M.; Diserens, J.; Ugazio, G.; Thomas, R.; Dominik, J. Water Res. 2003, 37, 2847.

5. Markich, S.J.; Brown, P.L. The Sci. Total Environ. 1998, 217, 201.

6. Chen, J.; Wang, F.; Xia, X.; Zhang, L. Chem. Geology. 2002, 187, 231.

7. Worku, Y.; Ejigu S.; Erge, W.; Jemaneh L. Ethiop. J. Health Dev. 1999, 13, 239.

8. Itanna, F. SINET: Ethiop. J. Sci. 1998, 21, 133.9.

9. Clesceri, L.S.; Greenberg, A.E.; Eaton, A.D.; Franson, M.A.H. Standard Methods for the Examination of Water and Wastewater, 20th ed., United Book Press: Maryland; 1998.

10. Canadian Council of Ministers of the Environment, http://www.ccme.ca/publications/

11. World Health Organization Assessment of fresh water quality-Global environmental monitoring system (GEMS) report on the related environmental monitoring, WHO; 1988.

12. Reeve, R. Introduction to Environmental Analysis, Wiley: England; 2002; p 59-61.

13. Indian Council of Medical Research Manual of Standards of Quality for Drinking Water Supplies, Indian Council of Medical Research, Spe. Rep. No. 1975, 44, 27.

14. Guéguen, C.; Gilbin, R.; Pardos, M.; Dominik, J. Appl. Geochem. 2004, 19, 153.

15. Jarvie, H.P.; Neal, C.; Leach, D.V.; Ryland, G.P.; House, W.A.; Robson, A.J. The Sci. Total Environ. 1997, 194/195, 285.

16. Jarvie, H.P.; Neal, C.; Tappin, A.D.; Burton, J.D.; Hill, L.; Neal, M.; Harrow, M.; Hopkins, R.; Watts C.; Wickham, H. The Sci Total Environ. 2000, 251/252, 55.

17. European Community (EC): Official Gazette NO. L. 229/11-229/29, 1980.

18. Environmental Protection Agency Is your drinking water safe? Environmental Protection Agency (WH-550), 570/9, 89-105, 1989.

19. Stoddard, J.L.; Jeffries, D.S.; Lukewille, A.; Clair, T.A.; Dillon, P.J.; Driscoll, C.T.; Forsius, M.; Johannessen, M.; Kahl, J.S.; Kellogg, J.H.; Kemp, A.; Mannio, J.; Monteith, D.T.; Murdoch, P.S.; Patrick, S.; Rebsdorf, A.; Skjelkvale, B.L.; Stainton, M.P.; Traaen, T.; Dam, H.; Webster, K.E.; Wieting, J.; Wilander, A. Nature 1999, 401, 575.

20. Markert, B.; Pedrozo, F.; Geller, W.; Friese, K.; Korhammer, S.; Bafficob, G.; Diaz, M.; Wolfl, S. The Sci. Total Environ. 1997, 206, 1. 